ANDREJA BRAJŠA-ŽGANEC

Institut društvenih znanosti Ivo Pilar, Zagreb

Andreja.Brajsa.Zganec@pilar.hr

\title{
KVALITETA ŽIVLJENJA, SREĆA I ŽIVOTNO ZADOVOLJSTVO U HRVATSKOJ I ZEMLJAMA EU, TE USPOREDBE SJEVEROZAPADNE I OSTALIH DIJELOVA HRVATSKE
}

Cilj ovog istraživanja bio je prikazati usporedne analize nekih od parametara koji određuju kvalitetu življenja, sreću i životno zadovoljstvo u različitim zemljama Europske Unije te na temelju hrvatskih istraživanja usporediti Sjeverozapadni dio u odnosu na ostale dijelove Hrvatske. Usporedbe kvalitete življenja u Hrvatskoj i zemljama članicama EU (EU28) pokazale su da građani Hroatske procjenjuju niže od europskog prosjeka svoje životno zadovoljstvo, financijsko stanje kućanstava, općenitu kvalitetu življenja te iskazuju niže razine povjerenja u državne institucije (vlada, parlament, pravosude, regionalnellokalne vlasti). Rezultati usporedbe različitih parametara kvalitete življenja između stanovnika Sjeverozapadne i ostalih dijelova Hrvatske pokazali su da su stanovnici Sjeverozapadne Hrvatske zadovoljniji svojim životom, zadovoljniji odnosima u obitelji i među prijateljima, osjećajem pripadnosti svojoj okolini i osjećajem sigurnosti u budućnosti. Također, u odnosu na ostale dijelove Hrvatske iskazali su više razine povjerenja u pravosude, policiju, školstvo, crkvu, zdravstvo i EU parlament. Ovakvi rezultati upućuju na zaključak da je općenita razina kvalitete življenja u nekim aspektima viša u Sjeverozapadnoj, nego u ostalim dijelovima Hrvatske. 


\section{UVOD}

Kvaliteta življenja, sreća i životno zadovoljstvo građana danas su nezaobilazni pojmovi kada se govori o stupnju razvoja društva. Dokument Ujedinjenih naroda (UN) „Izvješće o društvenom razvoju“ iz 1990. godine započinje definicijom o ljudskom razvoju koja kaže „Ljudi su istinsko nacionalno bogatstvo. Osnovni cilj razvoja jest stvoriti i omogućiti uvjete da bi ljudi mogli živjeti dugo, zdravo i kreativno. Ovo možda zvuči jednostavno. Međutim, to se često zaboravlja kada brinemo o stjecanju dobara i financijskog bogatstva." (UNDP, 1990). Od tada do danas prošlo je manje od trideset godina, a situacija u pogledu uvažavanja mišljenja i percepcija ljudi kada se govori o društvenom razvoju dramatično se promijenila. Kontinuirana mjerenja i praćenje tzv. subjektivnih indikatora dobrobiti provode se u brojnim zemljama diljem svijeta, što omogućuje uspoređivanje kroz vrijeme, države i regije. Osobito su u povoljnom položaju Europljani, jer se u Europi provode brojne studije kojima je za cilj redovito pratiti različite aspekte kvalitete življenja građana (Noll, 2008). Među tim studijama posebno valja istaknuti Europsku studiju vrednota (European Values Study), Europsko društveno istraživanje (European Social Survey), Europsko istraživanje kvalitete života (European Quality of Life Survey) i Eurobarometar (Eurobarometer), jer pored specifičnih indikatora koje mjere i prate, sve one uključuju i indikatore subjektivne dobrobiti. Institut društvenih znanosti Ivo Pilar od 2008. godine provodi istraživanja mišljenja i percepcija građana o društvenim odnosima i procesima pod nazivom "Pilarov barometar hrvatskog društva“ u kojima su uključeni i indikatori subjektivne dobrobiti. Budući da je Hrvatska od 2013. godine punopravna članica EU njezini građani sudjeluju i u periodičnim istraživanjima Eurobarometra.

Subjektivna dobrobit odnosi se na različite tipove evaluacija, dobre i loše, koje ljudi rade procjenjujući svoj život, različite životne događaje i uvjete u kojima žive (Diener, 2006). Ona uključuje emocionalnu komponentu, izraženu kroz osjećaj sreće te kognitivnu komponentu, izraženu kroz zadovoljstvo životom, zadovoljstvo poslom ili zadovoljstvo pojedinim životnim aspektima. Standardi i kriteriji na temelju kojih se procjenjuje zadovoljstvo životom zajednički su za većinu ljudi u većini kultura, a obavezno uključuju životni standard, odnose s drugim ljudima, zdravlje i sigurnost. Kvaliteta življenja širi je koncept koji obuhvaća obje komponente dobrobiti (sreću i životno zadovoljstvo), a Svjetska zdravstvena organizacija definira kvalitetu življenja kao „percepciju osobe o vlastitom životu u kontekstu kulturnog i vrijednosnog sustava u kojem živi, a s obzirom na svoje ciljeve, očekivanja i ograničenja“ (WHO, 1997.). To je multidimenzionalni koncept koji obuhvaća fizičko i mentalno zdravlje, stupanj neovisnosti, socijalne odnose, osobna uvjerenja i okolicu u kojoj pojedinac živi. Ovi različiti koncepti međusobno se prožimaju, ali im 
je zajedničko to da uvažavaju i mjere subjektivne doživljaje pojedinaca, a ne objektivne životne okolnosti. Kao što su istaknuli Stiglitz, Sen i Fitoussi (2009.) kada su na traženje tadašnjeg predsjednika Francuske N. Sarkozya imenovani u Komisiju za mjerenje ekonomskih učinaka i društvenog napretka (The Commission on the Measurement of Economic Performance and Social Progress) „kvaliteta življenja je širi pojam od životnog standarda i ekonomske produktivnosti. Ona uključuje cijeli niz čimbenika koji oblikuju ono što cijenimo u životu i poprilično je udaljena od materijalnog. Kvaliteta življenja uključuje mogućnosti koje ljudi imaju, značenje i smisao koje pridaju svojim životima i način na koji uživaju u onome što imaju."

Postavlja se pitanje zašto je uopće važno ispitivati percepcije građana, osobito njihove osjećaje sreće i životnog zadovoljstva. Novija istraživanja pokazuju da sretni i zadovoljni ljudi bolje funkcioniraju u različitim životnim područjima. Sretni i zadovoljni ljudi su zdraviji, žive duže, ostvaruju više prihode, produktivniji su i ostvaruju bolje socijalne odnose (Lyubomirski, King i Diener, 2005; Diener, 2013; Sirgy, 2012; Steptoe, Deaton i Stone, 2015). Doživljaj sreće i blagostanja potiče ljude da ostvaruju svoje ciljeve i izgrađuju kompetencije koje ih čine otpornima na moguće životne probleme i izazove (De Neve, Diener, Tay i Xuereb, 2013). Nije stoga neobično da su redovita mjerenja i praćenja sreće i životnog zadovoljstva danas nezaobilazni elementi državnih statistika u mnogim zemljama.

Cilj ovog istraživanja bio je prikazati usporedne analize nekih od parametara koji određuju kvalitetu življenja, sreću i životno zadovoljstvo u različitim zemljama Europske Unije te na temelju hrvatskih istraživanja usporediti Sjeverozapadni dio u odnosu na ostale dijelove Hrvatske. Podaci koji su korišteni za usporedne analize u EU preuzeti su iz Eurobarometra (Eurobarometer, 2015.), a za usporedbe unutar Hrvatske korišteni su podaci Pilarovog barometra hrvatskog društva (2015.), istraživanja koje je provedeno u proljeće 2015. godine na reprezentativnom uzorku hrvatskih građana.

\section{METODA SUDIONICI I POSTUPAK}

Istraživanje Eurobarometra provedeno je između 16. i 27. svibnja 2015. u 34 zemlje: 28 članica EU, pet zemalja kandidata (Makedonija, Turska, Crna Gora, Srbija i Albanija) te turski dio Cipra. Terenski dio istraživanja provodile su u svakoj pojedinoj zemlji odabrane agencije za istraživanja tržišta jedinstvenom metodologijom. U Hrvatskoj to je bila agencija Hendal na uzorku od N=1008 stanovnika starijih od 15 godina. Intervjui su rađeni metodom „licem u lice“ $u$ domovima izabranih sudionika. Uzorkovanje je u svakoj zemlji provedeno višeetapno, a broj mikrolokacija (sampling points) određen je proporcionalno broju stanovnika i gustoći naseljenosti, 
na način da budu obuhvaćene urbane i ruralne cjeline. U svakoj mikrolokaciji adrese potencijalnih sudionika izabrane su slučajnim postupkom, a u kućanstvu intervjuirana osoba izabrana je metodom „najbližeg rođendana“ (Eurobarometer, 2015.).

Istraživanje Pilarov barometar hrvatskog društva proveden je također u proljeće 2015. u razdoblju od 19. ožujka do 16. svibnja na reprezentativnom uzorku N=1000 punoljetnog stanovništva (18 i više godina). Uzorak je etapno stratificiran, uz očuvanu proporcionalnost i slučajni izbor jedinica unutar svakog stratuma. Obuhvaćene su sve županije, unutar kojih su naselja razvrstana prema formalnom kriteriju u gradska i ostala. Obuhvaćena su 102 naselja (143 mikrolokacije) u kojima je provedeno anketiranje, a kućanstva su na svakoj mikrolokaciji izabrana slučajnim sustavnim postupkom s popisa adresa, dok je izbor sugovornika unutar kućanstva proveden metodom „najbližeg rođendana“ (Pilarov barometar hrvatskog društva, 2015.).

Za usporedbe Sjeverozapadne u odnosu na ostale dijelove Hrvatske uzorak je podijeljen na dva dijela:

Stanovnici Krapinsko-zagorske, Zagrebačke, Varaždinske, Međimurske i Koprivničko-križevačke županije; njih $\mathrm{N}=196$, raspona dobi od 18 do 88 godina (M=51 god.) sa 55 \% žena i 45 \% muškaraca u uzorku.

Stanovnika ostalih dijelova Hrvatske bilo je N=804, istog raspona dobi od 18 do 88 godina (M=46 god.) sa 51 \% žena i 49 \% muškaraca u uzorku.

\section{INSTRUMENTI}

Zbog velikog broja parametara kvalitete života koji su odabrani za usporedbe te zbog preglednosti teksta, korišteni instrumenti i/ili pitanja na koja su sudionici odgovarali biti će pobliže prikazani u pojedinačnim usporedbama.

Za usporedbe kvalitete življenja u Hrvatskoj i zemljama članicama EU (EU28) korišteni su parametri: životno zadovoljstvo, procjena financijskog stanja kućanstava, očekivanja o financijskoj situaciji u idućih godinu dana, općenite procjene kvalitete življenja i povjerenje u državne institucije (vlada, parlament, pravosuđe, regionalne ili lokalne vlasti).

Za usporedbe Sjeverozapadne i ostalih dijelova Hrvatske korišteni su parametri: osjećaj sreće, osjećaj životnog zadovoljstva, zadovoljstvo osobnim područjima života, povjerenje $\mathrm{u}$ institucije i planovi o eventualnom odlasku u inozemstvo.

Za procjene zadovoljstva pojedinim životnim područjima korištena je Skala osobne dobrobiti (Personal Well-Being Indeks-PWI) Međunarodnog indeksa dobrobiti (International Well-Being Index-IWI), koji se u posljednjih desetak godina koristi u mnogim zemljama (Cummins i sur., 2003). Skala Osobne dobrobiti sastoji se od sedam čestica o različitim važnim životnim područjima o kojima sudionici procjenjuju svoje zadovoljstvo: životni standard, zdravlje, postignuća u životu, odnosi s 
obitelji i prijateljima, osjećaj sigurnosti, prihvaćenost od okoline u kojoj živite i osjećaj sigurnosti u budućnosti. Procjene se kreću od „0= uopće nisam zadovoljan/a“ do „10 = u potpunosti sam zadovoljan/a“. Rezultat se izražava kao procjena zadovoljstva na svakoj pojedinoj čestici te kao prosječno zadovoljstvo na svim česticama (PWI).

\section{REZULTATI I RASPRAVA HRVATSKA I EU}

U istraživanju Eurobarometra ispitano je između ostalog i životno zadovoljstvo građana zemalja EU28. Na pitanje „Gledajući općenito, da li ste svojim životom vrlo zadovoljni, djelomično zadovoljni, nezadovoljni ili vrlo nezadovoljni?“, u prosjeku je u svim zemljama $80 \%$ građana izjavilo da su vrlo ili djelomično zadovoljni svojim životom. Najzadovoljniji bili su građani Danske gdje ih je čak 99\% izjavilo da su zadovoljni, dok su najmanje zadovoljni bili građani Španjolske sa svega $42 \%$ zadovoljnih. Hrvatska je zauzela 22. mjesto sa 70\% vrlo ili djelomično zadovoljnih građana. Ovakav rezultat nije neočekivan, $u$ posljednjih desetak godina u različitim se istraživanjima životnog zadovoljstva građana Hrvatska obično nalazi u zadnjoj trećini europskih zemalja, međutim, valja imati u vidu da se u svjetskim razmjerima sve EU zemlje nalaze u gornjoj polovici zadovoljnih građana (Helliwell, Layard i Sachs, 2015.).

Na pitanje „Kako biste procijenili sadašnju financijsku situaciju svog kućanstva“, 68 \% građana EU28 procijenilo ju je dobrom. I u ovom parametru na vrhu ljestvice su Danci, kojih 93\% procjenjuje da im je financijska situacija dobra, a na dnu Španjolci sa 42\% građana koji vlastitu financijsku procjenjuju dobrom. Hrvatska je zauzela 24. mjesto, sa 51\% građana koji smatraju da im je financijska situacija dobra. Sličnost u položaju pojedinih zemalja pri procjenjivanju životnog zadovoljstva i osobne financijske situacije djelomično je rezultat činjenice da s porastom prihoda kućanstva raste i životno zadovoljstvo građana (Diener, Tay i Oishi, 2013), što je utvrđeno i u našem ranijem istraživanju provedenom u Hrvatskoj (Kaliterna Lipovčan, Brkljačić i Šakić, 2007).

Očekivanja hrvatskih građana u budućnosti nešto su viša nego prosjek EU28. Na pitanje „Što očekujete u idućih dvanaest mjeseci, hoće li se vaša financijska situacija biti bolja, lošija ili ista?" 25\% hrvatskih građana odgovorilo je da će biti bolja, dok je prosjek EU28 bio 23\%. Po ovom parametru zauzeli smo 10. mjesto među 28 EU zemalja, najveći optimizam iskazali su Irci sa 34\% onih koji su očekivali bolju financijsku situaciju, a najmanji optimizam Danci sa svega $15 \%$. Ovakav rezultat samo na prvi pogled izgleda paradoksalno, budući da su Danci iskazali najviše životno zadovoljstvo u EU28, međutim, oni su iskazali i najveće zadovoljstvo svojom financijskom situacijom (93\% ih je smatralo da je ona dobra), pa je logično da ne očekuju niti priželjkuju znatna poboljšanja. 
Procjenjujući općenito kvalitetu življenja u svojoj zemlji, 60\% građana EU28 procijenilo ju je dobrom. Najviše procjene opet su u Danskoj (94\%), najniže u Bugarskoj (11\%), dok su hrvatski građani pri dnu ljestvice sa svega 23\% građana koji kvalitetu življenja procjenjuju dobrom.

Razina povjerenja u javne institucije važan je parametar društvenog kapitala, kvalitete društva i znatno utječe na dobrobit građana. Niske razine povjerenja kakve se tipično bilježe u postkomunističkim društvima (Bjornskov, 2006) mogu rezultirati izostankom sudjelovanja građana u javnim akcijama, izbjegavanjem plaćanja poreza i društvenom fragmentacijom u mnogim područjima (Eurofound, 2014).

Općenito, povjerenje u institucije u Hrvatskoj znatno je niže od prosjeka EU28. U nacionalnu vladu povjerenje je iskazalo svega $21 \%$ hrvatskih građana, dok je prosjek EU bio 31\%. Najveće povjerenje iskazali su Finci (60\%), a najmanje Španjolci (12\%). U nacionalni parlament vjeruje prosječno 31\% građana EU28, a svega 19\% hrvatskih građana. Najviše povjerenja u parlament imali su opet Finci (62\%), a najmanje Španjolci (12\%). U pravosuđe vjeruje svega 33\% hrvatskih građana, nasuprot najviše rangiranim Dancima, kojih čak $87 \%$ iskazuje povjerenje u pravosuđe. Najniže rangirani bili su stanovnici Bugarske sa svega 20\%, a prosjek EU28 bio je $52 \%$ građana koji vjeruju u pravosuđe u svojoj zemlji. Po povjerenju u regionalne/lokalne vlasti hrvatski su građani na samom začelju EU28 sa svega $20 \%$ onih koji vjeruju regionalnim i/ili lokalnim vlastima, prosjek EU28 bio je $47 \%$, a najviše povjerenje iskazali su Danci $(72 \%)$.

Očigledno je iz ovih rezultata da hrvatske političke elite trebaju puno toga učiniti kako bi se poboljšalo povjerenje građana u državne institucije, osobito u regionalne i lokalne vlasti. Njihov rad potrebno je učiniti transparentnijim i odgovornijim prema građanima te povećati mogućnost za građansko i političko sudjelovanje u društvu, jer ono pridonosi ukupnoj kvaliteti društva poboljšanjem subjektivnog blagostanja i jačanjem osjećaja građanske solidarnosti (Eurofound, 2014).

\section{SJEVEROZAPADNA HRVATSKA U ODNOSU NA OSTALE HRVATSKE REGIJE}

Nakon pregleda nekih od najvažnijih parametara kvalitete življenja i osobnog zadovoljstva građana na razini Europske Unije, prikazat ćemo usporedne analize tih i nekih drugih parametara unutar Hrvatske, usporedbom Sjeverozapadnih županija i ostalih dijelova Hrvatske. Statistička značajnost razlika između različitih parametara procijenjenih od strane stanovnika Sjeverozapadne i stanovnika ostalih dijelova Hrvatske računala se t-testom. 
Osjećaj sreće i životnog zadovoljstva dva su pokazatelja subjektivne dobrobiti građana. Sreća predstavlja emocionalnu komponentu dobrobiti, a životno zadovoljstvo kognitivnu evaluaciju ukupnih životnih prilika (Diener, 2006).

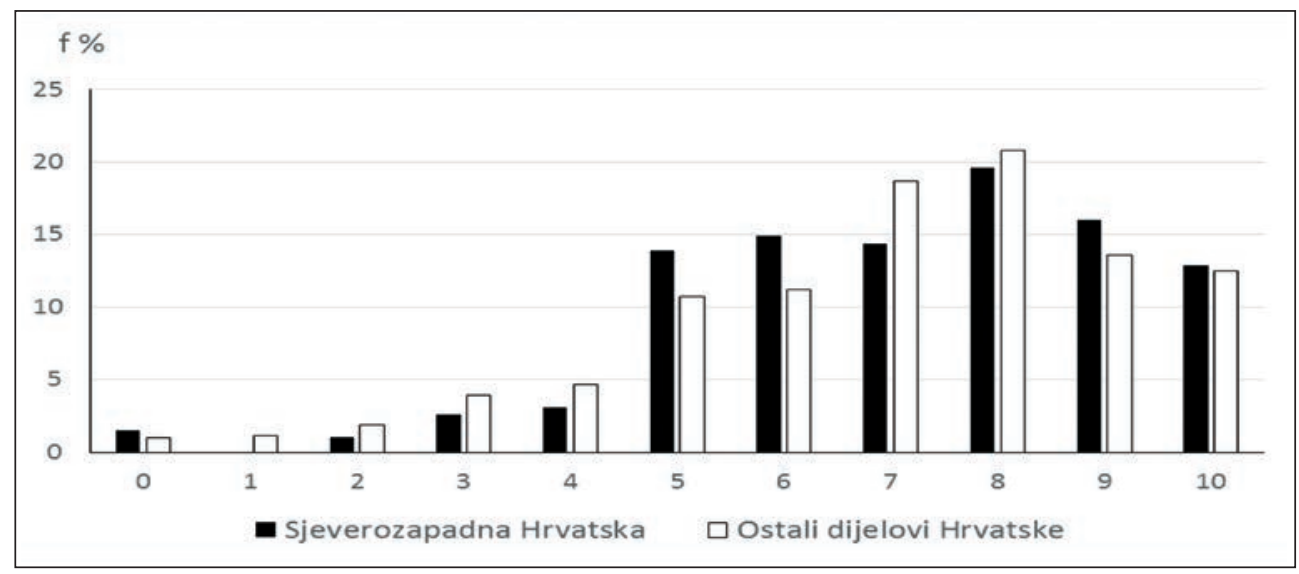

Slika 1. Općenito govoreći, koliko se osjećate sretnim/sretnom? Nula znači da uopće niste sretni, a 10 da ste izrazito sretni/sretna.

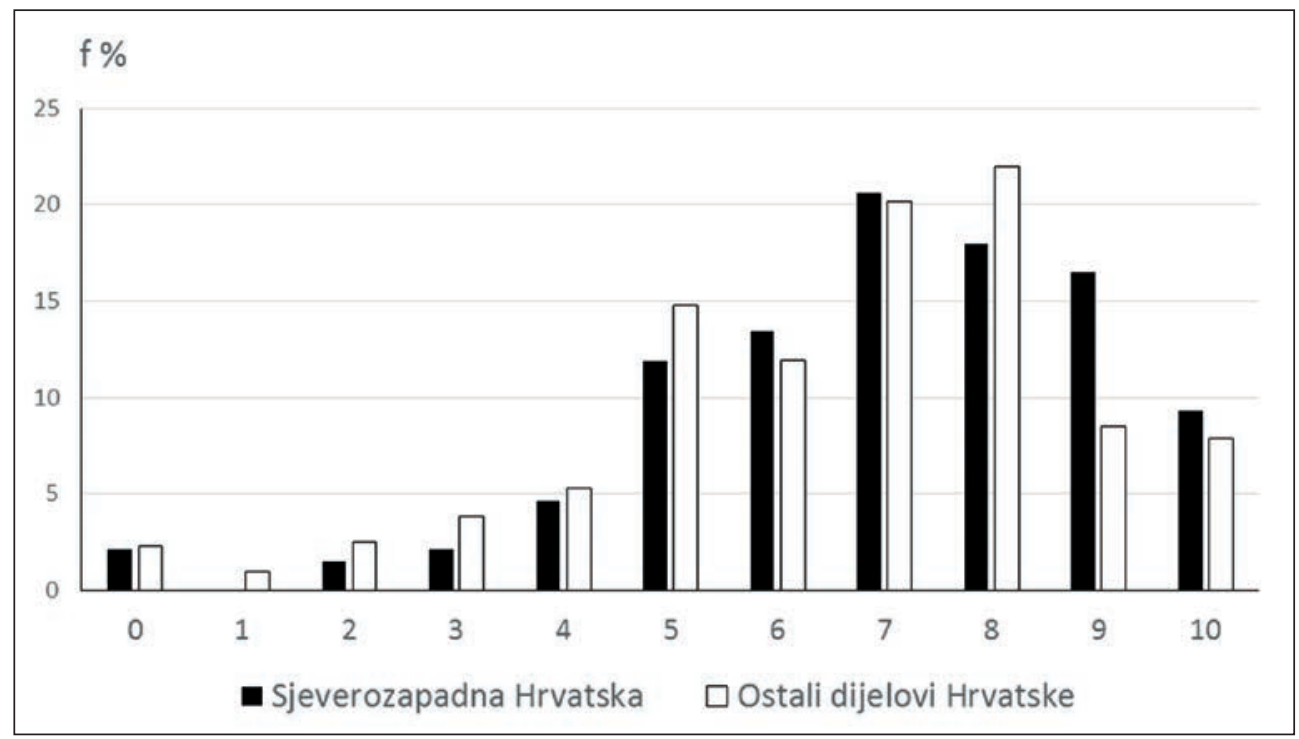

Slika 2. Koliko ste zadovoljni svojim životom u cjelini?

Nula znači da uopće niste zadovoljni, a 10 da ste izrazito zadovoljni. 
Kao što se vidi iz distribucije odgovora na ljestvicama sreće i životnog zadovoljstva, općenito se može reći da su obje komponente subjektivne dobrobiti procijenjene relativno visoko kod hrvatskih građana. Najčešći odgovori na pitanje o sreći i životnom zadovoljstvu kretali su se oko 7 i 8 , s prosječnom vrijednošću sreće na razini cijele Hrvatske $\mathrm{M}=7,07$ ( $\mathrm{SD}=2,21)$, a životnog zadovoljstva $\mathrm{M}=6,67$ ( $\mathrm{SD}=2,23)$.

Stanovnici Sjeverozapadne Hrvatske nisu se statistički značajno razlikovali po svojim procjenama sreće $u$ odnosu na stanovnike ostalih dijelova, međutim, iskazali su značajno višu razinu životnog zadovoljstva, s prosječnom procjenom $M=7,02$ $(\mathrm{SD}=2,14)$, dok su u ostalim dijelovima Hrvatske stanovnici životno zadovoljstvo procijenili prosječnom procjenom $\mathrm{M}=6,59(\mathrm{SD}=2,47 ; \mathrm{t}=2,41 ; \mathrm{p}<0,01)$. Najveća razlika u pojedinačnim procjenama iskazana je na procjeni ",9“, gdje je 16,5\% stanovnika Sjeverozapadne Hrvatske izrazilo tako visoko zadovoljstvo životom, u odnosu na svega $8,5 \%$ stanovnika u ostalim dijelovima Hrvatske.

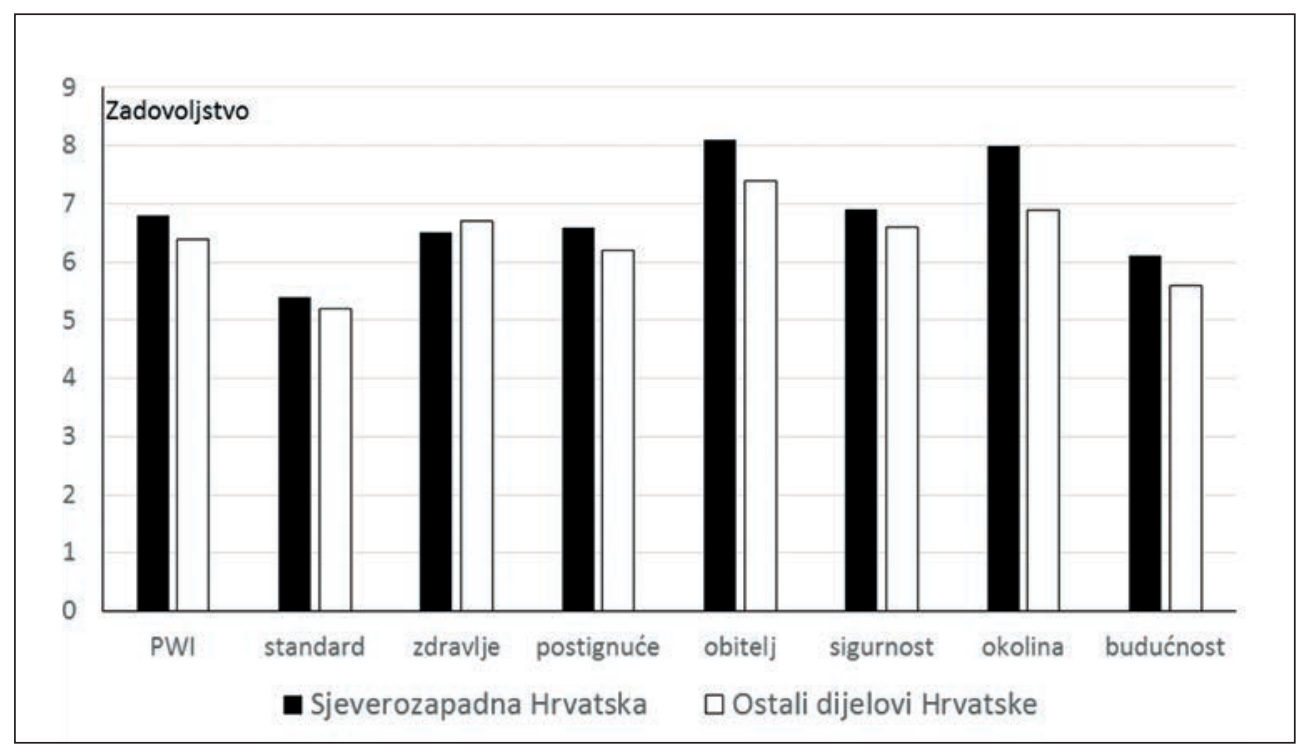

Slika 3. Koliko ste zadovoljni sljedećim pojedinostima u svom životu?

Nula znači da uopće niste zadovoljni, a 10 da ste izrazito zadovoljni. (PWI-Skala osobne dobrobiti) 
Gledajući općenito, hrvatski građani najviše su zadovoljni svojim odnosima s obitelji i prijateljima te prihvaćenošću od okoline u kojoj žive, a najmanje zadovoljni svojim životnim standardom. Ovakve procjene dobivene su i u našim prijašnjim istraživanjima (Kaliterna Lipovčan i Prizmić, 2006).

Analizirajući razlike pokazalo se da su stanovnici Sjeverozapadne Hrvatske statistički značajno zadovoljniji svojim odnosima s obitelji i prijateljima $(\mathrm{t}=3,94$; $\mathrm{p}<0,01)$, prihvaćenošću od okoline $u$ kojoj žive $(t=6,07 ; p<0,01)$ te osjećajem sigurnosti u budućnosti $(\mathrm{t}=2,29 ; \mathrm{p}<0,05)$. Zadovoljstvo odnosima $\mathrm{s}$ obitelji stanovnici Sjeverozapadne Hrvatske procijenili su prosječnom ocjenom $\mathrm{M}=8,07(\mathrm{SD}=1,98)$, a prihvaćenost od okoline $\mathrm{M}=8,01 ; \mathrm{SD}=2,06)$ u odnosu na $\mathrm{M}=7,38(\mathrm{SD}=2,21)$ koliko je iznosila prosječna procjena odnosa u obitelji i $\mathrm{M}=6,86(\mathrm{SD}=2,42)$ prihvaćenost od okoline kod stanovnika ostalih dijelova Hrvatske. Budući da su harmonični međuljudski odnosi i socijalna podrška koju pojedinci dobivaju od drugih ljudi jedna od glavnih odrednica životnog zadovoljstva (Sarason, Sarason i Pierce, 1990), ovako visoke procjene vjerojatno su i jedan od razloga relativno visoko procijenjenog životnog zadovoljstva stanovnika Sjeverozapadne Hrvatske.

Kao što smo već istaknuli u prethodnom poglavlju, povjerenje u različite državne i javne institucije važna je sastavnica društvenog kapitala, upućuje na kvalitetu društva i znatno utječe na subjektivnu dobrobit građana.

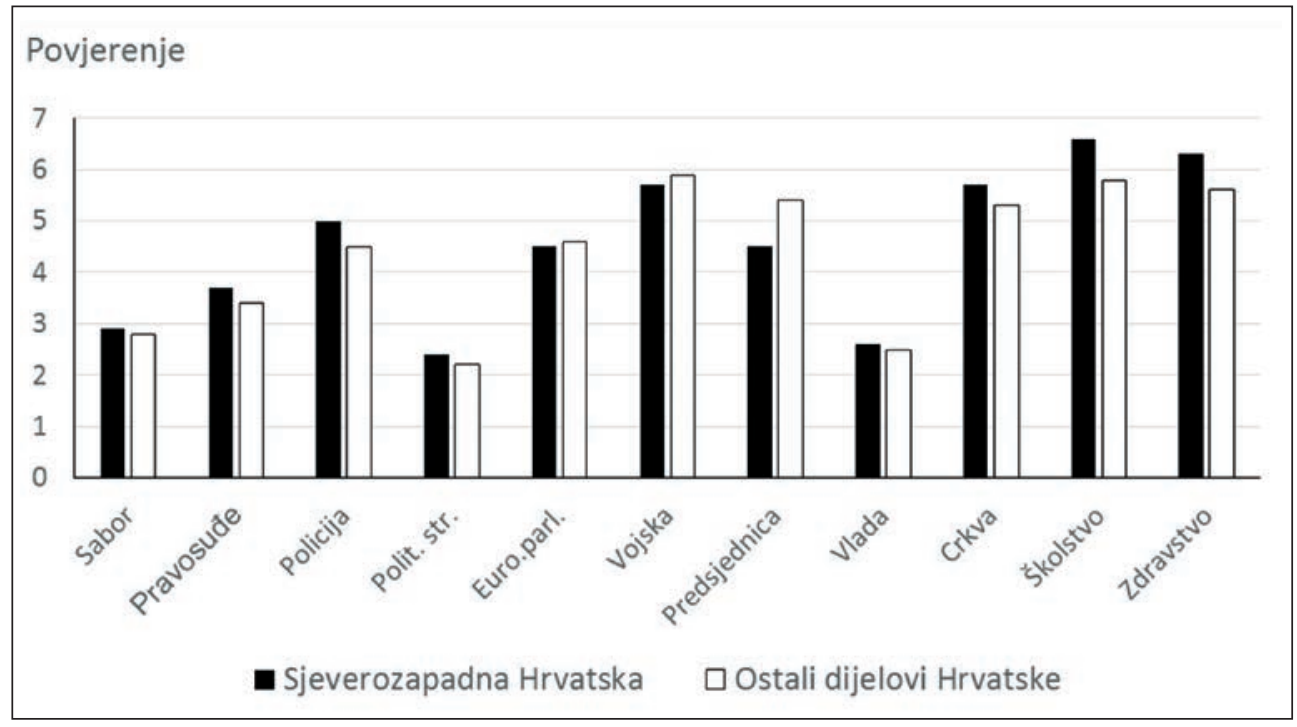

Slika 4. Koliko Vi osobno imate povjerenja u sljedeće institucije? Nula znači da uopće nemate povjerenja, a 10 da imate potpuno povjerenje. 
Općenito, stanovnici Hrvatske znatno veće povjerenje iskazuju prema javnim institucijama (vojska, policija, zdravstvo, crkva, školstvo), nego državnim/političkim (sabor, vlada, predsjednik, političke stranke). Stanovnici Sjeverozapadne Hrvatske u odnosu na ostale dijelove Hrvatske iskazali su statistički značajno veće povjerenje $u$ policiju ( $\mathrm{t}=1,99 ; \mathrm{p}<0,05)$, $\mathrm{zdravstvo}(\mathrm{t}=3,65 ; \mathrm{p}<0,01)$ i školstvo $(\mathrm{t}=4,00 ; \mathrm{p}<0,01)$ te manje $\mathrm{u}$ predsjednicu $\mathrm{RH}(\mathrm{t}=3,57 ; \mathrm{p}<0,01)$. Povjerenje $\mathrm{u}$ institucije, kao jedan od elemenata društvenog kapitala, važna je odrednica kvalitete društva. Istraživanja pokazuju da društveni kapital direktno i indirektno povećava dobrobit građana, promovirajući sustav socijalne podrške i aktivirajući građane da se uključe u društveni život, što ima za posljedicu bolje funkcioniranje javne administracije pa čak i smanjenje troškova poslovanja u različitim sektorima (Sachs, 2016). Podaci Hrvatske gospodarske komore o indeksu gospodarske snage županija pokazuju da se svih pet promatranih županija Sjeverozapadne Hrvatske po tom indeksu nalaze u gornjoj polovici hrvatskih županija, što je također moglo utjecati na veće povjerenje u javne institucije stanovnika Sjeverozapadne u odnosu na ostale stanovnike Hrvatske (HGK, 2017., str. 4).

I na kraju, budući da se u posljednjih nekoliko godina intenzivno govori o tzv. "odljevu mozgova“ i odlasku mladih ljudi na rad u inozemstvo, zanimalo nas je koliko je ta pojava prisutna u hrvatskom društvu.

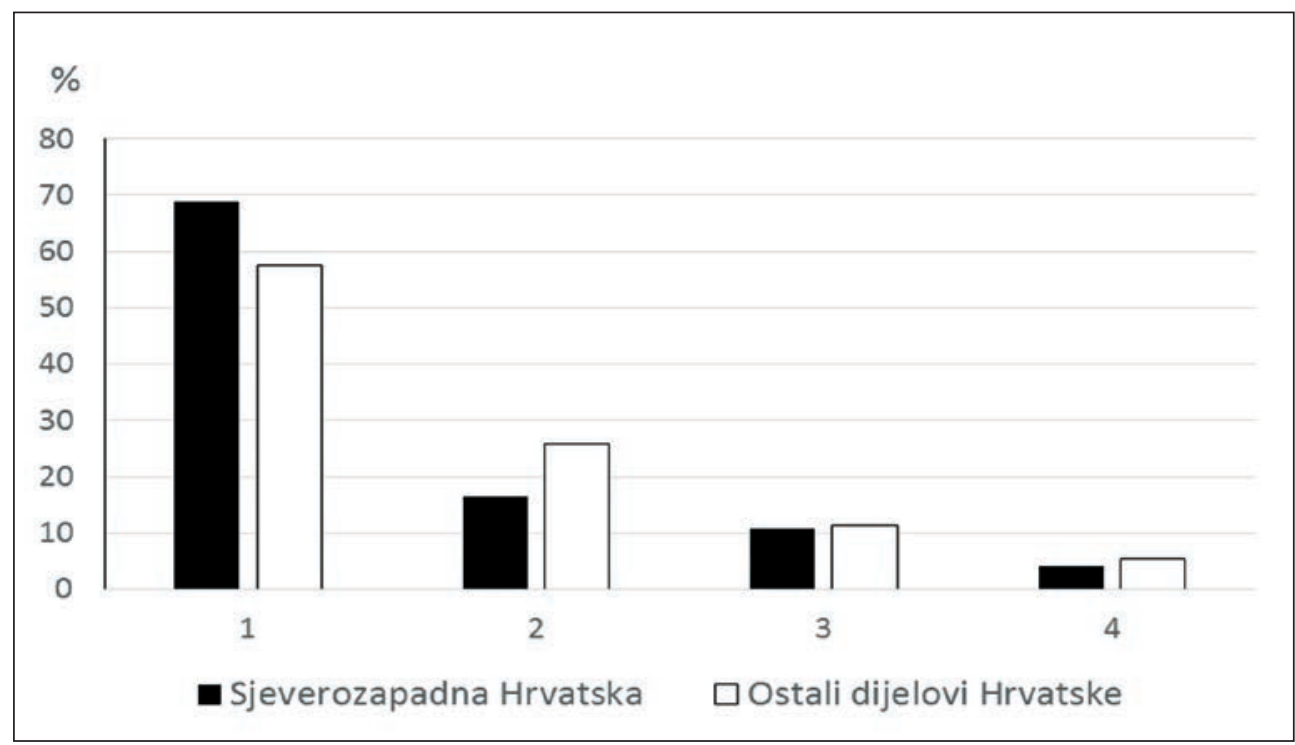

Slika 5. Planirate li u skorije vrijeme napustiti Hrvatsku i otići živjeti u inozemstvo? $1=$ uopće ne planiram, svakako želim ostati u Hrvatskoj; 2= ponekad razmišljam o tome; 3= često razmišljam o tome; 4= planiram, svakako želim otići u inozemstvo 
Kao što se vidi na Slici 5., velika većina hrvatskih građana uopće ne planira otići u inozemstvo (60,7\%), dok ih realno planira 4,5\%. Statistički značajne razlike između stanovnika Sjeverozapadne i ostalih dijelova Hrvatske nisu utvrđene, iako postoji trend da nešto više građana Sjeverozapadne Hrvatske želi ostati u Hrvatskoj i ne planira iseliti $(68,7 \%$ u odnosu na $57,6 \%$ ), a nešto manje njih ponekad razmišlja o tome $(16,4 \%$ u odnosu na $25,8 \%)$ ili planira iseliti (4,1\% u odnosu na $5,4 \%)$. Ovakav trend rezultata moguća je posljedica više razine životnog zadovoljstva, zadovoljstva nekim važnim životnim područjima i povjerenja u različite institucije koje su utvrđene kod stanovnika Sjeverozapadne Hrvatske. Također, valja istaknuti da je stopa nezaposlenosti u pet promatranih županija Sjeverozapadne Hrvatske 2015. godine iznosila prosječno 16,5 dok je u ostalim dijelovima Hrvatske bila 24,6. Prosjek za cijelu Hrvatsku bio je 19,3 (DZS, 2017).

\section{ZAKLJUČAK}

Hrvatski građani u odnosu na građane drugih zemalja Europske Unije iskazali su nešto niže razine životnog zadovoljstva i kvalitete življenja, zadovoljstva svojom financijskom situacijom, te relativno niske razine povjerenja u javne i državne institucije. Osobito su niskim procijenili povjerenje u regionalne i lokalne vlasti, po čemu je Hrvatska 2015. godine bila na samom začelju EU. Niže procjene financijske situacije i životnog zadovoljstva možemo smatrati očekivanima s obzirom na relativno loše gospodarske uvjete u zemlji u to vrijeme. Međutim, povjerenje u državne institucije, osobito lokalne i regionalne vlasti vrlo su važan čimbenik kvalitete društva i znatno utječu na percepcije ljudi o vlastitoj dobrobiti. Stoga se nameće zaključak da bi se političke elite u Hrvatskoj morale odgovornije ponašati te svoj rad učiniti transparentnijim, kako bi se poboljšale percepcije građana o važnim institucijama, kao što su pravosuđe, vlada, sabor i osobito lokalne vlasti.

Uspoređujući percepcije građana o različitim elementima kvalitete življenja i osobnog zadovoljstva između Sjeverozapadne i ostalih dijelova Hrvatske, pokazalo se da su stanovnici Sjeverozapadne Hrvatske zadovoljniji svojim životom, zadovoljniji odnosima u obitelji i među prijateljima, osjećajem pripadnosti svojoj okolini i osjećajem sigurnosti u budućnosti. Također, u odnosu na ostale dijelove Hrvatske iskazali su više razine povjerenja u pravosuđe, policiju, školstvo, crkvu, zdravstvo i EU parlament. Ovakvi rezultati upućuju na zaključak da je općenita razina kvalitete življenja u nekim aspektima viša u Sjeverozapadnoj, nego u ostalim dijelovima Hrvatske. Treba, međutim, imati u vidu metodološko ograničenje ovog istraživanja, koje se očituje u nerazmjerno većem broju sudionika ostalih regija ( $\mathrm{N}=804)$ u odnosu na one iz Sjeverozapadne Hrvatske (N=196). Zbog toga utvrđene razlike treba promatrati više kao trendove, nego kao stvarne razlike. 
Razumijevanje i praćenje dobrobiti građana na lokalnim i regionalnim razinama je ključno za stvaranje javnih politika koje imaju za cilj boljitak društva (OECD, 2016). Pored međunarodnih usporedbi, posljednjih godina sve više raste interes za utvrđivanjem subnacionalnih/regionalnih razlika u indikatorima subjektivne dobrobiti, jer takve usporedbe mogu točnije utvrditi potrebe i aspiracije ljudi u lokalnim zajednicama te omogućiti ciljane akcije za poboljšanje životnih prilika građana (Brezzi and Diaz Ramirez, 2016). U Hrvatskoj nedostaje istraživanja koja bi omogućila regionalne usporedbe, a ona su najpotrebnija upravo sada kada se očekuju reforme u različitim javnim sektorima, od zdravstva do obrazovanja. Samo redovito praćenje kvalitete življenja građana može nam pružiti uvid u način na koji društvene promjene utječu na percepcije i očekivanja građana (Kim-Prieto i sur., 2005). Takva istraživanja i kreiranje javnih politika temeljenih na njihovim rezultatima omogućilo bi i vraćanje povjerenja građana u državne institucije.

\section{LITERATURA}

1. C. BJORNSKOV, (2006) Determinants of generalised trust: a cross-country comparison. Public Choice, 130:1-21.

2. M. BREZZI, i M. DIAZ RAMIREZ, (2016) Building subjective well-being indicators at the subnational level: A preliminary assessment in OECD regions, OECD Regional Development Working Papers, 2016/03, OECD Publishing, Paris.

3. R. A. CUMMINS, R. ECKERSLEY, J. PALLANT, J. VAN VUGT, i R. MISAJON, (2003). Developing a national index of subjective wellbeing: The Australian Unity Wellbeing Index. Social Indicators Research, 64, 159-190.

4. J. DE NEVE, E. DIENER, L. TAY, i C. XUEREB, (2013) The objective benefits of subjective wellbeing. CEP discussion paper no. 1236. Centre for economic performance, London.

5. E. DIENER, (2006) Guidelines for National Indicators of Subjective Well-Being and Ill-Being. Journal of Happiness Studies, 7 (4):397-404.

6. E. DIENER, (2013) The remarkable changes in the science of subjective wellbeing. Perspectives in Psychological Sciences, 8:663-666.

7. E. DIENER, L. TAY, i S. OISHI, (2013) Rising income and subjective well-being in nations. Journal of Personality and Social Psychology, 104 (2):267-276.

8. DZS (2017) Statističke informacije. Državni zavod za statistiku Republike Hrvatske, Zagreb 2017. 
9. EUROBAROMETER (2015) Standard Eurobarometer 83 / Spring 2015: Public Opinion in the European Union. Brussels: European Commission, DirectorateGeneral for Communication.

10. EUROFOUND (2014) Trendovi u kvaliteti života - Hrvatska 2007.-2012.., Ured za publikacije europske Unije, Luxemourg.

11. J. F. HELLIWELL, R. LAYARD, i J. SACHS, ur. (2015) World Happiness Report 2015. New York: Sustainable Development Solutions Network.

12. HGK (2017) BDP i gospodarska snaga županija. Hrvatska gospodarska komora - Odjel za makroekonomske analize. Zagreb, 2017.

13. LJ. KALITERNA LIPOVČAN, Z. PRIZMIĆ, (2006) Importance and satisfaction with life domains in Croatia: representative sample. U: Estes R.J. (ur.) Quality of Life in a Turbulent World. Dordrecht: Springer, 41-51.

14. LJ. KALITERNA LIPOVČAN, T. BRKLJAČIĆ, i V. ŠAKIĆ, (2007) Mjesečni prihodi i subjektivni osjećaj zadovoljstva hrvatskih građana. Croatian Medical Journal, 48(5):727-733.

15. C. KIM-PRIETO, E. DIENER, M. TAMIR, C. SCOLLON, i M. DIENER, (2005). Integrating the diverse definitions of happiness: A time-sequential framework of subjective well-being. Journal of Happiness Studies, 6, 261-300.

16. S. LYUBOMIRSKY, L. KING, E. DIENER, (2005) The benefits of frequent positive affect: Does happiness lead to success? Psychological Bulletin, 131:803-855.

17. H. H. NOLL, (2008) European Survey Data: Rich Sources for Quality of Life Research. U: Moller, V., Huschka, D. i Michalos, A.C. (ur.) Barometers of Quality of Life Around the Golbe. How Are We Doing?. Dodrecht, The Netheralnds: Springer.

18. OECD (2016) OECD Regional well-being users guide: using data to build better communities. Paris: OECD Publishing.

19. PILAROV BAROMETAR HRVATSKOGA DRUŠTVA (2015), Zagreb: Institut društvenih znanosti Ivo Pilar. Dostupno na http://barometar.pilar.hr

20. J. SACHS, (2015) Investing in social captal. U: Helliwell, John F., Richard Layard, and Jeffrey Sachs (ur.) World Happiness Report 2015. New York: Sustainable Development Solutions Network. 152-166.

21. I. G. SARASON, B. R. SARASON, i G. R. PIERCE, (1990) Social support: the search for theory. Journal of Social and Clinical Psychology, 9 (1):133-147.

22. M. J. SIRGY, (2012) The psychology of quality of life. Hedonic wellbeing, life satisfaction and eudemonia, 2nd edn. Springer, Dordrecht. 
23. A. STEPTOE, A. DEATON, A. A. STONE, (2015) Subjective wellbeing, health, and ageing. Lancet 385:640-648.

24. J. STIGLITZ, A. SEN, i J. P. FITOUSSI (2009), The Measurement of Economic Performance and Social Progress Revisited, Dostupno na: https://www.ofce. sciences-po.fr/pdf/dtravail/WP2009-33.pdf

25. UNDP (1990) Human Development Report - Published for the United Nations Development Programme, New Yourk: Oxford University Press.

26. WHO (1997) WHOQOL Measuring Quality of Life, Report of The Division of Mental Health and Prevention of Substance Abuse, Geneve: World Health Organisation WHO/MSA/MNH/PSF/97.4

\section{SAŽETAK}

\section{KVALITETA ŽIVLJENJA, SREĆA I ŽIVOTNO ZADOVOLJSTVO U HRVATSKOJ I ZEMLJAMA EU, TE USPOREDBE SJEVEROZAPADNE I OSTALIH DIJELOVA HRVATSKE}

Sreća, životno zadovoljstvo i druge subjektivne procjene građana o vlastitom životu i percepciji društvenih pojava danas sve više postaju nezaobilazne komponente pri praćenju društvenog razvoja, ravnopravne različitim ekonomskim pokazateljima. Cilj ovog istraživanja bio je prikazati usporedne analize nekih od parametara koji određuju kvalitetu življenja, sreću i životno zadovoljstvo u različitim zemljama Europske Unije te na temelju hrvatskih istraživanja usporediti Sjeverozapadni dio u odnosu na ostale dijelove Hrvatske. Podaci koji su korišteni za usporedne analize u EU preuzeti su iz istraživanja Eurobarometar iz 2015. godine u kojem su provedena istraživanja u 28 zemalja članica EU i nekoliko zemalja kandidata. Za usporedbe unutar Hrvatske korišteni su podaci istraživanja Pilarov barometar hrvatskog društva, koje je provedeno u proljeće 2015. godine na reprezentativnom uzorku hrvatskih građana ( $\mathrm{N}=1000)$. Za usporedbe Sjeverozapadne u odnosu na ostale dijelove Hrvatske uzorak je podijeljen na dva dijela: (1) stanovnike Krapinsko-zagorske, Zagrebačke, Varaždinske, Međimurske i Koprivničko-križevačke županije (N=196) i (2) stanovnike ostalih dijelova Hrvatske (N=804). Statistička značajnost razlika u pojedinim parametrima računala se t-testom. Usporedbe kvalitete življenja u Hrvatskoj i zemljama članicama EU (EU28) pokazale su da građani Hrvatske procjenjuju niže od europskog prosjeka svoje životno zadovoljstvo, financijsko stanje kućanstava, općenitu kvalitetu življenja te iskazuju niže razine povjerenje u državne institucije (vlada, parlament, pravosuđe, regionalne/lokalne vlasti). Osobito su niske bile razine povjerenja u regionalne i/ili lokalne vlasti gdje je Hrvatska zauzela zadnje mjesto unutar zemalja EU28. Jedini parametar koji je bio procijenjen iznad europskog prosjeka bila su očekivanja o financijskoj situaciji u idućih godinu dana, gdje su hrvatski građani iskazali iznadprosječni optimizam. Rezultati usporedbe različitih parametara kvalitete življenja između stanovnika sjeverozapadne i ostalih dijelova Hrvatske pokazali su da su stanovnici Sjeverozapadne Hrvatske zadovoljniji svojim životom, zadovoljniji odnosima u obitelji i 
među prijateljima, osjećajem pripadnosti svojoj okolini i osjećajem sigurnosti u budućnosti. Također, u odnosu na ostale dijelove Hrvatske iskazali su više razine povjerenja u pravosuđe, policiju, školstvo, crkvu, zdravstvo i EU parlament. Ovakvi rezultati upućuju na zaključak da je općenita razina kvalitete življenja u nekim aspektima viša u Sjeverozapadnoj, nego u ostalim dijelovima Hrvatske.

Ključne riječi: kvaliteta života; sreća; životno zadovoljstvo; Hrvatska; EU.

\section{SUMMARY}

\section{QUALITY OF LIFE, HAPPINESS AND LIFE SATISFACTION IN CROATIA AND EU COUNTRIES, AND COMPARING NORTHWESTERN AND OTHER PARTS OF CROATIA}

Together with economic indices, happiness, life satisfaction and other subjective perceptions about quality of life and various societal processes in contemporary world became unavoidable in monitoring nation's social progress. The aim of this study was to compare several parameters that determine quality of life and life satisfaction between citizens of Croatia and other countries in the European Union (EU28). The second aim was to compare within Croatia the same parameters between citizens of North-West region and the rest of Croatia. The data for comparisons between Croatia and EU28 were based on the Eurobarometer survey conducted in 2015 in all countries of EU and several candidate countries. The data for comparisons within Croatia were based on the survey Pilar's barometer of Croatian society, which was conducted in spring of 2015 on the representative sample of Croatian citizens ( $N=1000)$. For the purposes of these analyses the sample was devided into: (1) citizens of KrapinaZagorje, Zagreb, Varaždin, Međimurje and Koprivnica-Križevci counties (N=196) and (2) citizens of the other regions of Croatia $(\mathrm{N}=804)$. Statistical differences were determined by $\mathrm{t}$-test analyses. The comparisons of quality of liofe indices between Croatia and EU28 showed that citizens of Croatia rated their life satisfaction, financial situation in households, general quality of life and trust in various institutions (government, parliament, justice, regional/local authorities) lower than EU28 averages. Especially low citizens rated their trust in local/regional authorities, where Croatia was at the last position within EU28. The only parameter which was rated above EU28 average were expectations about financial situation in one year, where Croatian citizens showed higher optimism than EU28 average. Comparisons within Croatia showed that citizens of North-West region of Croatia expressed higher levels of life satisfaction, satisfaction with family and friends, satisfaction with their feelings of acceptance by the community and feelings of safety in the future. Besides that, citizens of North-West region of Croatia showed higher levels of trust in justice, police, education system, church, health care and EU parliament than the citizens in other regions of Croatia. These results indicate that quality of life in North-West region of Croatia is somewhat higher in several components than in other parts of Croatia.

Key Words: quality of life; happiness; life satisfaction; Croatia; EU. 